\title{
The effect of thinning on humus conditions in spruce and beech stands in the Highlands area of the Czech Republic
}

\author{
Ladislav Menšík ${ }^{1}$ Eva Kostková1 Jiří Kulhavý $^{1}$ \\ ${ }^{1}$ Department of Forest Ecology, Faculty of Forestry and Wood Technology, Mendel University in Brno, Zemédèlská 3, \\ Brno 613 00, Czech Republic,email: ladislav.mensik@mendelu.cz
}

\begin{abstract}
Menšík L., Kostková E., Kulhavý J. 2015: The effect of thinning on humus conditions in spruce and beech stands in the Highlands area of the Czech Republic. - Beskydy, 8 (2): $101-110$

The study evaluates the effect of the type of thinning (above thinning vs. below thinning) on the humus conditions (i.e. forest floor stock, the content and stock of carbon and nitrogen, $\mathrm{C} / \mathrm{N}$ ratio, and the proportion of carbon in humic substances) in spruce stands found on acid granodiorite (acid site) in forest vegetation zone (FVZ) 4 to 5 (Field research station Rájec-Němčice /FRS/, Department of Forest Ecology /DFE/ Mendel University in Brno) and in beech stands found on a solidified limestone sediment (nutrient rich site) in FVZ 3 to 4 (Training Forest Enterprise Masaryk Forest Křtiny /TFE Křtiny/); the sites indicated above are part of the upland of Drahanská vrchovina Upland (Czech Republic). Thinning was conducted in spruce stand in 2005, 2010; in beech stand in 2011. The stock of forest floor was determined to be 17-18 tha $\mathrm{ha}^{-1}$ under the beech stands and 51-54 t.ha in the stands of spruce. The $\mathrm{C} / \mathrm{N}$ ratio in the layers of forest floor and soil horizons at each site is similar and is not statistically significantly different. In spruce and beech stands in layers $\mathrm{F}$ and $\mathrm{H}$ fulvic acids prevail - a lower HA to FA ratio, the transformation of humic substances is more complete in layer $\mathrm{H}$ under spruce stands compared with beech. In the Ah horizon, the situation is reversed, with the transformation of humic substances being more complete under beech stands. The results incorporated using multivariate statistical methods (PCA) confirmed that thinning has no statistically significant effect on humus conditions in young spruce and beech stands in different types of habitats.
\end{abstract}

Keywords: type of thinning, spruce and beech stands; forest floor and soil; Drahanská vrchovina Upland, the Czech Republic

\section{Introduction}

Currently, the impact of thinning on biogeochemical cycles /i.e. soil organic matter, decomposition processes, nutrient cycling, etc./ is currently insufficiently studied in the Czech Republic and abroad (Vesterdal et al. 1995; Podrázský et al. 2005; Menšík et al. 2009ab; Novák et al. 2011). Thinning affect accumulation, transformation and mineralisation of soil organic matter in several ways: the quantity and quality of tree litter (Šály 1978; Binkley, Giardina 1998; Novák, Slodičák 2004 etc.); accelerated mineralisation /decayed organic matter/ (Šarman 1979, 1982; Nilsen et al. 2008).
The quality of humic substances is important for soil fertility and nutrition of forest stands. It differs based on the various natural conditions, whether they are geological, geomorphological, climatic, stand-related or other. Therefore humic substances are studied in detail mainly in economically important ecosystems (Menšík 2010). Soil organic matter ("SOM") is generally defined as the sum of all non-living organic components of soil (Stevenson 1994). In terms of chemical and analytical characteristics humus can be divided into non-humic substances (organic substances of plant and animal origin) and humic substances (produced from nonhumic substances and soil-specific). 
The aim of the study was to evaluate the effect of the type of thinning (above thinning vs. below thinning) on the humus conditions (i.e. forest floor stock, the content and stock of carbon and nitrogen, $\mathrm{C} / \mathrm{N}$ ratio, and the proportion of carbon in humic substances) in spruce stands found on acid granodiorite (acid site) in FVZ 4 to 5 and in beech stands found on a solidified limestone sediment (nutrient rich site) in FVZ 3 to 4; the sites are part of the Drahanská vrchovina Upland (Czech Republic).

\section{Materials and methods}

\section{The area of interest, research plots}

The research was conducted in natural forest area (NFA) 30 - Drahanská vrchovina Upland. Research in humus conditions has been locally underway since 1977. For this project, the research focused on forest stands (research plots) at sites differing from each other in terms of climate, typology, and soil: (1) spruce monoculture - in the second generation, the age of 35 years (above thinning /Spruce 1/, below thinning / Spruce 2/), part of the Research facility RájecNěmčice; and (2) beech stand - in the second generation, the age of 45 years (above thinning /Beech 1/, below thinning /Beech 2/), part of the Training Forest Enterprise Masaryk Forest Krrtiny. Thinning was conducted in spruce monoculture in 2005, 2010; in beech stand in 2011. A more comprehensive description of the experimental stands is given in Tab. 1 .

The parent rock is an intrusive rock of acid granodiorite /Spruce stand/ and shale, greywacke and solidified limestone sediment/Beech stand/.

Sampling: Samples for determining the stock of forest floor (L, F, H) were collected in autumn (in October 2012 in spruce stand, 2014 in beech stand), using a metal frame (Menšík et al. 2012) of $0.1 \mathrm{~m}^{2}$, there were five repetitions for each variant. Samples for chemical analysis of forest floor and soil were sampled as follows: L mixed; $\mathrm{F}, \mathrm{H}(\mathrm{F}+\mathrm{H}), \mathrm{Ah}, \mathrm{Bvl}(\mathrm{Btml})$ in three repetitions for each variant; Bv2 (Bmt2) and Bcg as a mixed sample. Samples for physical analysis: three steel cylinders $\left(100 \mathrm{~cm}^{3}\right)$ were taken at all sampling sites from each horizon in mineral soil.

Chemical analysis: Carbon and nitrogen were determined using samples cleared from coarser particles after they were finely ground; the determination was made using the automatic analyser LECO TruSpec /MI USA/ (Zbíral 1997). Humic substances were extracted from the fine soil by a solution of sodium pyro-phosphate in an alkaline mixture $+\mathrm{NaOH}$ using short fractionation by Kononová and Bělčiková (Podlešáková et al. 1992). The colour quotient $\left(Q_{4 / 6}\right)$ of HA solutions was measured using a spectrophotometer LIBRA S22 UV/VIS (Biochrom) at a wavelength of $465 \mathrm{~nm}$ and $665 \mathrm{~nm}$. The $Q_{4 / 6}$ coefficient was determined by dividing the observed values of absorbance (Kononová 1963). The degree of humification (DH) of soil organic matter (\%) was calculated according to the relation: $\mathrm{DH} \mathrm{I}(\%)=$ $=100 * \mathrm{C}_{\mathrm{HL}} / \mathrm{C}_{\text {org }}$ according to Sotáková (1982), Orlov (1985). UV/VIS spectra of humic acids were measured using a spectrophotometer UNICAM $8625 \mathrm{UV} / \mathrm{VIS}$, the range being $400 \mathrm{~nm}$ to $700 \mathrm{~nm}$, with the pitch of $10 \mathrm{~nm}$ (Podlešáková et al. 1992).

Physical analysis: The soil density was determined by pycnometry (Jandák et al. 2003). Skeleton content were determined by ocular estimate describing soil profile.

Statistical analysis: Statistical analysis, including graphical outputs, were carried out using STATISTICA 12.0 (Stat-Soft Inc., Tulsa USA, StatSoft ČR s.r.o. 2014). The comparison of stands (variant) was made using the nonparametric statistical analysis of Kruskal-Wallis and F-test as an ANOVA alternative, because the data did not meet the requirements for the homogeneity of variance. Principal Component Analysis (PCA) was used for interpreting the physico-chemical properties of humus and soil.

Tab. 1: Basic characteristic of forest stand.

\begin{tabular}{|c|c|c|c|c|c|c|c|c|}
\hline & $\begin{array}{c}\text { Age } \\
\text { [years] }\end{array}$ & $\begin{array}{c}\text { Stand } \\
\text { Structure } \\
{[\%]} \\
\end{array}$ & $\begin{array}{l}\text { Form } \\
\text { of Forest } \\
\text { Floor }^{+}\end{array}$ & Soil type & $\begin{array}{l}\text { A.S.L. } \\
{[\mathrm{m}]}\end{array}$ & $\begin{array}{c}\text { Rainfall } \\
{[\mathrm{mm}]}\end{array}$ & $\begin{array}{c}\text { Temp. } \\
{\left[{ }^{\circ} \mathbf{C}\right]}\end{array}$ & Forest Typology \\
\hline $\begin{array}{l}\text { Spruce stands } \\
\text { (Spruce 1, 2) }\end{array}$ & 38 & $\begin{array}{l}\text { Picea abies } \\
\text { (L.) Karst } \\
100\end{array}$ & moder & $\begin{array}{c}\text { Modal } \\
\text { oligotrophic } \\
\text { Cambisol }^{+}\end{array}$ & 632 & $638^{*}$ & $6.5^{*}$ & $\begin{array}{l}\text { 5S1-Abieto-Fagetum } \\
\text { mesotrophicum with } \\
\text { Oxalis acetosella }\end{array}$ \\
\hline $\begin{array}{l}\text { Beech stands } \\
\text { (Beech 1,2) }\end{array}$ & 45 & $\begin{array}{c}\text { Fagus } \\
\text { sylvatica L. } \\
100\end{array}$ & mull-moder & $\begin{array}{c}\text { Modal } \\
\text { mesotrophic } \\
\text { Pseudogley }^{\dagger}\end{array}$ & 470 & $596^{* *}$ & $7.9^{* *}$ & $\begin{array}{l}\text { 3H1-Querceto- } \\
\text { Fagetum illimerosum } \\
\text { mezotrophicum }\end{array}$ \\
\hline
\end{tabular}

${ }^{\dagger}$ (Nëmeček et al. 2011); ${ }^{+\dagger}$ taxonomy by FMI (Forest Management Institute, Brandýs nad Labem); ${ }^{*}$ Pivec 1992);

**(Truhlár 1996) 
Selected measured characteristics were used as predictors (factors); they were chosen on the basis of an eigenvalue graph. Variables with impaired assumption of normality were converted using logarithmic transformation. As part of step 1, PCA was carried out with all the variables to compute the most important variables. Step 2 involved selecting active and supplementary variables for better interpretation. This stepwise analysis significantly improves the outcome of the PCA analysis in case of a smaller number of samples. PCA was used for calculating a component weight for the investigated variables (Meloun, Militký 2011). Based on correlations and contributions in convincing factors each of the characteristics was subsequently judged for relevance to explain the multidimensional dependencies (correlations) in the factorial plane. Statistical significance was assessed at a significance level of $P=0.05$ (Meloun, Militký 2012).

\section{Results}

\section{The form of forest floor and type of soil}

As regards humus form, moder was identified in spruce stands (Spruce 1, 2), and mull in beech stands. In terms of soil type, the research plots contain modal oligotrophic cambisols in the spruce forest and modal mesotrophic pseudogley in beech stands (Němeček et al. 2011).

\section{Forest floor stock}

The stock of forest floor was determined per layer under the stands of both spruce (Spruce 1,2 ) and beech, with the L, F, and $H$ layer depth fluctuating between 3 and $5 \mathrm{~cm}$. The total stock of forest floor was found to be 51.5 to $53.7 \mathrm{t}^{-h^{-1}}$ in spruce forest (Spruce 1, 2), and 16.8 to 18.1 t.ha ${ }^{-1}$ in stands of beech (Beech 1, 2). As regards the individual layers and the total stock, statistically significant differences were not demonstrated at $p=0.05$, see Fig. 1 . - currently, thinning do not have a significant impact on these parameters.

\section{The content of carbon and nitrogen, $\mathrm{C} / \mathrm{N}$ ratio in the forest floor and mineral soil}

For carbon and nitrogen content, stands of spruce and beech did not show statistically significant differences at a significance level of $p=$ 0.05 in the individual layers of forest floor and the soil horizons within the sites - thinnig had no effect on these parameters. $\mathrm{C} / \mathrm{N}$ ratio is similar in the individual layers of forest floor and the soil horizons within the stands (spruce/beech) - it does not differ significantly (no statistically significant difference observed), see Fig. 2 - currently, thinning do not have a significant impact on these parameters.

\section{The stock of carbon and nitrogen in the forest floor and mineral soil}

Carbon/nitrogen stock in the forest floor in the SM stands was set at 20.7 to 21.4 t.ha $^{-1}$ (0.7 t.ha ${ }^{-1}$ of nitrogen in the forest floor); for beech stands, the forest floor layer stock was calculated to amount 4.3 to 4.7 t.ha-1 $\left(0.1\right.$ to 0.2 t.ha ${ }^{-1}$ of nitrogen in the forest floor) see Tabs. 1 and 2.

For soil horizons Ah and BV, the stock of carbon/nitrogen in stands of spruce (to a depth of $50 \mathrm{~cm}$ ) ranges from 68.4 to 72.4 t.ha $^{-1}$ (3.1 to 3.4 t.ha ${ }^{-1}$ of nitrogen). For beech stands, the stock in the soil horizons Ah and Bmt (to a depth of $50 \mathrm{~cm}$ ) was calculated to be 76.8 to 77.5 t.ha $^{-1}$ (6.2-7.0 t.ha ${ }^{-1}$ of nitrogen). It can be concluded based on the results that currently thinning do not have a significant impact on the stock of carbon and nitrogen.
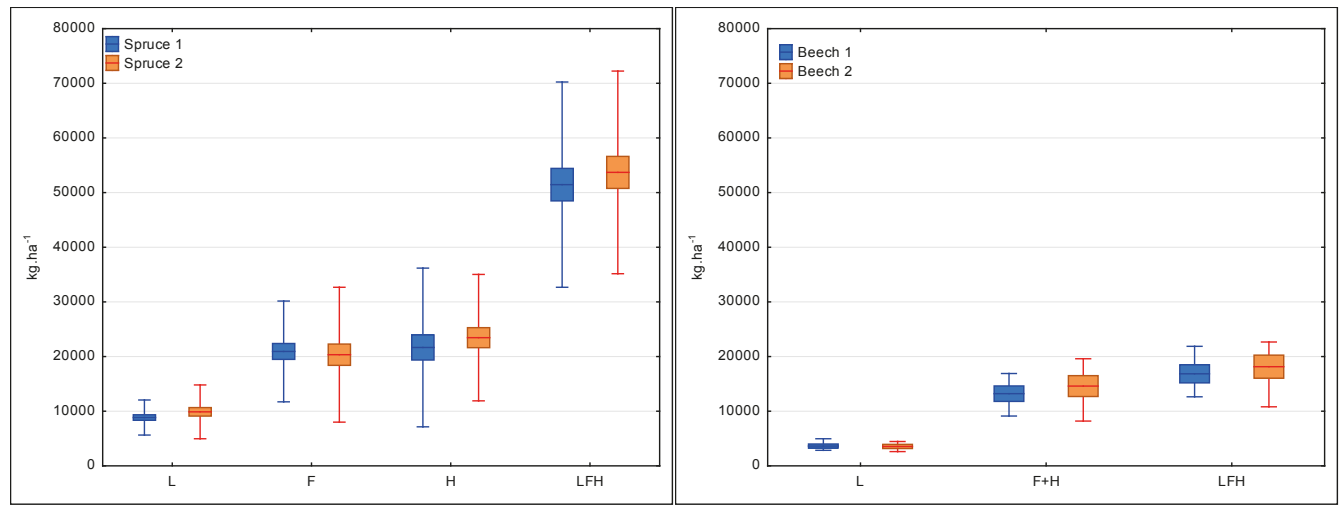

Fig. 1. The stock of forest floor per layer and the total stock per variant of stand of spruce and beech. Note: the statistical analysis in spruce stands (Spruce 1, 2) made use of data from 2012-2014. 

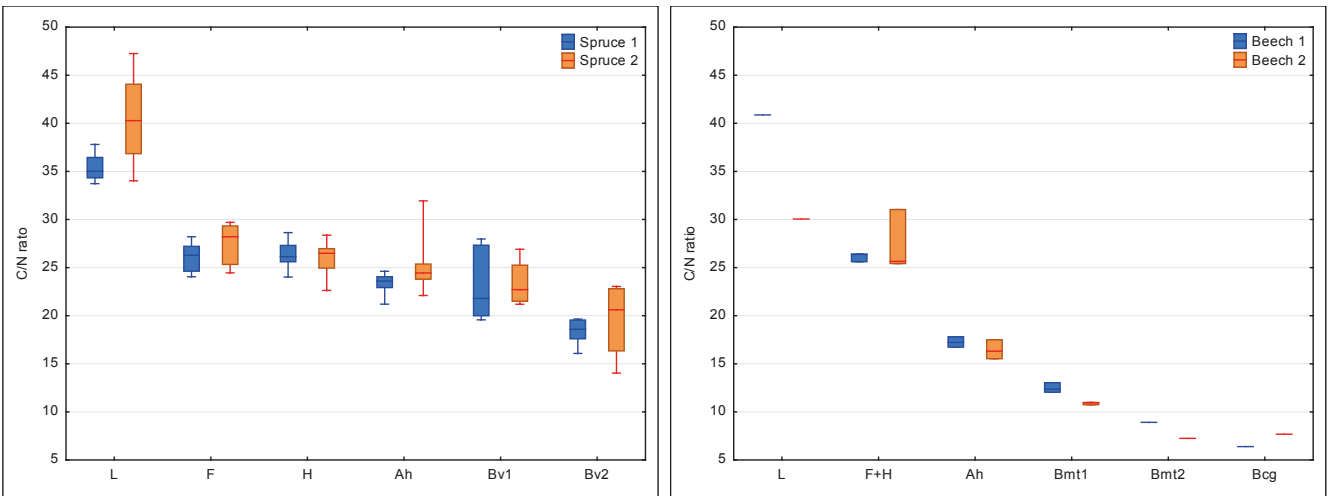

Fig. 2. C/N ratio in the layers of forest floor and the soil horizons per variant of stand of spruce and beech.

Note: the statistical analysis in spruce stands (Spruce 1,2) made use of data from 2012-2014.

Tab. 1. Calculation of carbon (C) stock in the layers of forest floor and the soil horizons to a depth of $50 \mathrm{~cm}$ per variant of stand of spruce and beech.

\begin{tabular}{|c|c|c|c|c|c|c|c|c|c|}
\hline \multirow[t]{2}{*}{ Plot } & \multirow[t]{2}{*}{$\begin{array}{c}\text { Layer/ } \\
\text { horizon }\end{array}$} & $\begin{array}{c}\text { Layer/ } \\
\text { horizon } \\
\text { thickness }\end{array}$ & $\begin{array}{l}\text { Forest } \\
\text { floor } \\
\text { stock }\end{array}$ & $\begin{array}{c}\text { Soil mass } \\
\text { density }\end{array}$ & $\begin{array}{c}\text { Skeleton } \\
\text { content }\end{array}$ & $\begin{array}{c}\text { Carbon } \\
\text { /C/ } \\
\text { content }\end{array}$ & $\begin{array}{c}\text { Carbon } / \mathrm{C} / \\
\text { stock per } \\
\text { layer and } \\
\text { horizon }\end{array}$ & $\begin{array}{c}\text { Carbon /C/ } \\
\text { stock in } \\
\text { forest floor } \\
\text { and mineral } \\
\text { soil }\end{array}$ & $\begin{array}{c}\text { Total } \\
\text { carbon } \\
\text { /C/ stock }\end{array}$ \\
\hline & & $\mathrm{cm}$ & t.ha-1 & kg. $\mathrm{m}^{-3}$ & $\%$ & $\%$ & \multicolumn{3}{|c|}{ t.hat } \\
\hline \multirow{6}{*}{$\begin{array}{c}\text { Spruce } \\
1\end{array}$} & $\mathrm{~L}$ & 2 & 8.9 & & & 47.9 & 4.2 & \multirow{3}{*}{20.7} & \multirow{6}{*}{93.1} \\
\hline & $\mathrm{F}$ & 3 & 20.9 & & & 44.2 & 9.3 & & \\
\hline & $\mathrm{H}$ & 2 & 21.7 & & & 33.4 & 7.2 & & \\
\hline & Ah & 1 & & 1419 & & 8.4 & 12.0 & \multirow{3}{*}{72.4} & \\
\hline & Bvl & 25 & & 1419 & 10 & 1.2 & 39.0 & & \\
\hline & Bv2 & 25 & & 1385 & 20 & 0.8 & 21.4 & & \\
\hline \multirow{6}{*}{$\begin{array}{c}\text { Spruce } \\
2\end{array}$} & $\mathrm{~L}$ & 2 & 9.9 & & & 49.0 & 4.8 & \multirow{3}{*}{21.4} & \multirow{6}{*}{89.8} \\
\hline & $\mathrm{F}$ & 3 & 20.2 & & & 43.8 & 8.8 & & \\
\hline & $\mathrm{H}$ & 2 & 23.5 & & & 33.1 & 7.8 & & \\
\hline & Ah & 1 & & 1342 & & 9.0 & 12.0 & \multirow{3}{*}{68.4} & \\
\hline & Bvl & 25 & & 1,342 & 10 & 1.2 & 36.4 & & \\
\hline & Bv2 & 25 & & 1,541 & 20 & 0.6 & 19.9 & & \\
\hline \multirow{5}{*}{$\begin{array}{c}\text { Beech } \\
1\end{array}$} & $\mathrm{~L}$ & 1 & 3.6 & & & 45.2 & 1.6 & \multirow{2}{*}{4.3} & \multirow{5}{*}{81.1} \\
\hline & $\mathrm{F}+\mathrm{H}$ & 2 & 13.2 & & & 20.4 & 2.7 & & \\
\hline & Ah & 4 & & 1025 & & 6.9 & 28.4 & \multirow{3}{*}{76.8} & \\
\hline & Bmtl & 21 & & 1630 & 2 & 0.9 & 31.0 & & \\
\hline & Bmt2 & 25 & & 1612 & 5 & 0.5 & 17.4 & & \\
\hline \multirow{5}{*}{$\begin{array}{c}\text { Beech } \\
2\end{array}$} & $\mathrm{~L}$ & 2 & 3.6 & & & 42.9 & 1.5 & \multirow{2}{*}{4.7} & \multirow{5}{*}{82.2} \\
\hline & $\mathrm{F}+\mathrm{H}$ & 3 & 14.6 & & & 21.9 & 3.2 & & \\
\hline & $\mathrm{Ah}$ & 4 & & 933 & & 9.5 & 35.5 & \multirow{3}{*}{77.5} & \\
\hline & Bmtl & 21 & & 1664 & 2 & 0.7 & 25.2 & & \\
\hline & Bmt2 & 25 & & 1623 & 5 & 0.4 & 16.8 & & \\
\hline
\end{tabular}

Note: Calculating stock estimates in spruce stands (Spruce 1,2) used data from 2012-2014. 
Tab.2. Calculation of the stock of nitrogen $(N)$ in the layers of forest floor and soil horizons to a depth of $50 \mathrm{~cm}$ in the variants of spruce and beech stands

\begin{tabular}{|c|c|c|c|c|c|c|c|c|c|}
\hline \multirow[t]{2}{*}{ Plot } & \multirow[t]{2}{*}{$\begin{array}{c}\text { Layer/ } \\
\text { horizon }\end{array}$} & $\begin{array}{c}\text { Layer/ } \\
\text { horizon } \\
\text { thickness }\end{array}$ & $\begin{array}{c}\text { Forest } \\
\text { floor } \\
\text { stock }\end{array}$ & $\begin{array}{c}\text { Soil mass } \\
\text { density }\end{array}$ & $\begin{array}{c}\text { Skeleton } \\
\text { content }\end{array}$ & $\begin{array}{c}\text { Nitrogen } \\
/ \mathbf{N} / \\
\text { content }\end{array}$ & $\begin{array}{l}\text { Nitrogen } \\
\text { /N/ stock } \\
\text { per layer } \\
\text { and } \\
\text { horizon }\end{array}$ & $\begin{array}{c}\text { Nitrogen } \\
\text { /N/ stock } \\
\text { in forest } \\
\text { floor and } \\
\text { mineral soil }\end{array}$ & $\begin{array}{c}\text { Total } \\
\text { nitrogen } \\
\text { /N/ } \\
\text { stock }\end{array}$ \\
\hline & & $\mathbf{c m}$ & t.ha-1 & kg. $\mathbf{m}^{-3}$ & $\%$ & $\%$ & \multicolumn{3}{|c|}{ t.ha-1 } \\
\hline \multirow{6}{*}{$\begin{array}{c}\text { Spruce } \\
1\end{array}$} & $\mathrm{~L}$ & 2 & 8.9 & & & 1.35 & 0.1 & \multirow{3}{*}{0.7} & \multirow{6}{*}{4.2} \\
\hline & $\mathrm{F}$ & 3 & 20.9 & & & 1.69 & 0.4 & & \\
\hline & $\mathrm{H}$ & 2 & 21.7 & & & 1.26 & 0.3 & & \\
\hline & Ah & 1 & & 1419 & & 0.36 & 0.5 & \multirow{3}{*}{3.4} & \\
\hline & Bvl & 25 & & 1419 & 10 & 0.05 & 1.7 & & \\
\hline & Bv2 & 25 & & 1385 & 20 & 0.04 & 1.2 & & \\
\hline \multirow{6}{*}{$\begin{array}{c}\text { Spruce } \\
2\end{array}$} & $\mathrm{~L}$ & 2 & 9.9 & & & 1.23 & 0.1 & \multirow{3}{*}{0.7} & \multirow{6}{*}{3.9} \\
\hline & $\mathrm{F}$ & 3 & 20.2 & & & 1.59 & 0.3 & & \\
\hline & $\mathrm{H}$ & 2 & 23.5 & & & 1.28 & 0.3 & & \\
\hline & Ah & 1 & & 1342 & & 0.36 & 0.5 & \multirow{3}{*}{3.1} & \\
\hline & Bvl & 25 & & 1342 & 10 & 0.05 & 1.6 & & \\
\hline & Bv2 & 25 & & 1541 & 20 & 0.03 & 1.1 & & \\
\hline \multirow{5}{*}{$\begin{array}{c}\text { Beech } \\
1\end{array}$} & $\mathrm{~L}$ & 1 & 3.6 & & & 1.11 & 0.0 & \multirow{2}{*}{0.1} & \multirow{5}{*}{6.2} \\
\hline & $\mathrm{F}+\mathrm{H}$ & 2 & 13.2 & & & 0.78 & 0.1 & & \\
\hline & Ah & 4 & & 1025 & & 0.40 & 1.6 & \multirow{3}{*}{6.1} & \\
\hline & Bmtl & 21 & & 1630 & 2 & 0.07 & 2.5 & & \\
\hline & Bmt2 & 25 & & 1612 & 5 & 0.05 & 1.9 & & \\
\hline \multirow{5}{*}{$\begin{array}{c}\text { Beech } \\
2\end{array}$} & L & 2 & 3.6 & & & 1.43 & 0.1 & \multirow{2}{*}{0.2} & \multirow{5}{*}{7.0} \\
\hline & $\mathrm{F}+\mathrm{H}$ & 3 & 14.6 & & & 0.80 & 0.1 & & \\
\hline & Ah & 4 & & 933 & & 0.58 & 2.2 & \multirow{3}{*}{6.8} & \\
\hline & Bmtl & 21 & & 1664 & 2 & 0.07 & 2.3 & & \\
\hline & Bmt2 & 25 & & 1623 & 5 & 0.06 & 2.3 & & \\
\hline
\end{tabular}

Note: Calculating stock estimates in spruce stands (Spruce 1,2) used data from 2012-2014.

\section{The proportion of carbon in the humus substances}

The analysis of fractionation of humic substances determined the fractions of carbon in the mixed representative samples. The highest levels of forest floor/ $\mathrm{C}_{\text {org }}$ in the spruce stand variants were shown to exist in forest floor layer H. Fulvic acids prevail each time in the fraction composition; the HA to FA ratio is lesser than 1 . The values of colour Q4/6 - colour quotient $\left(Q_{4 / 6}\right)$ are high (6-7), indicating the prevalence of FA, see Tab. 3 .

The degree of humification was calculated as the $\mathrm{HL} / \mathrm{C}_{\text {org }} * 100$ ratio. The values are low $(20 \%)$ to moderate $(30 \%)$. The degree of humification was seen to be moderate for $\mathrm{F}$ and $\mathrm{H}$, and low for
A. UV-VIS spectra are the highest at the lower wavelengths (400 nm), where they absorb FA, which is confirm through the $\mathrm{Q}_{4 / 6}$ ratio.

In the beech stand variants, the humus content $/ \mathrm{C}_{\text {org }}$ in the $\mathrm{F}+\mathrm{H}$ layer of forest floor is very high (>20\%). The sum of HL is also very high (3\%). The quality of humus is low. For the fractional composition, fulvic acids (FA) are predominant of humic acids (HA). The HA to FA ratio is less than 1. The values of colour Q4/6 - colour quotient $Q_{4 / 6}$ range from 4 to 5, indicating acidic fulvate type of humus. The degree of humification is low (to $20 \%$ ). The absorbance in the UV-VIS spectral region is higher than for Bmt and Ah horizons. 
Tab. 3. The fractionation of humic substances in the layers of forest floor and soil horizons per spruce stand variant.

\begin{tabular}{|c|c|c|c|c|c|c|c|c|c|c|}
\hline Stand & Horizon & $\mathrm{C}_{\text {org }}(\%)$ & $\begin{array}{c}\text { Humus } \\
(\%)\end{array}$ & $\begin{array}{l}\text { HS } \\
\text { (\%) }\end{array}$ & $\begin{array}{l}\text { HA } \\
\text { (\%) }\end{array}$ & $\begin{array}{l}\text { FA } \\
\text { (\%) }\end{array}$ & $\begin{array}{c}\text { HA/ FA } \\
\text { ratio }\end{array}$ & $\mathbf{Q}_{4 / 6}$ & DH & pH (KCl) \\
\hline \multirow{3}{*}{$\begin{array}{c}\text { Spruce } \\
1\end{array}$} & $\mathbf{F}$ & 5.75 & 9.91 & 1.30 & 0.45 & 0.85 & 0.55 & 5.95 & 22.50 & 3.35 \\
\hline & H & 7.10 & 12.24 & 1.79 & 0.82 & 0.98 & 0.77 & 6.60 & 25.21 & 2.67 \\
\hline & Ah & 6.75 & 11.64 & 1.11 & 0.48 & 0.63 & 0.76 & 7.00 & 16.47 & 3.40 \\
\hline \multirow{3}{*}{$\begin{array}{c}\text { Spruce } \\
2\end{array}$} & $\mathbf{F}$ & 6.17 & 10.63 & 1.37 & 0.47 & 0.90 & 0.53 & 5.80 & 22.14 & 3.31 \\
\hline & $\mathbf{H}$ & 7.40 & 12.76 & 1.73 & 0.78 & 0.95 & 0.78 & 6.60 & 23.56 & 2.73 \\
\hline & Ah & 6.90 & 11.90 & 1.14 & 0.45 & 0.62 & 0.73 & 7.00 & 16.54 & 3.40 \\
\hline
\end{tabular}

Note: HS - humic substances; HA - humic acids; FA - fulvic acids; $Q_{4 / 6}$ - colour quotient; $\mathrm{DH}$ - degree of humification

Tab. 4. The fractionation of humic substances in the layers of forest floor and soil horizons per beech stand variant.

\begin{tabular}{|c|c|c|c|c|c|c|c|c|c|c|}
\hline Stand & Horizon & $\mathrm{C}_{\text {org }}(\%)$ & $\begin{array}{c}\text { Humus } \\
(\%)\end{array}$ & $\begin{array}{l}\text { HL } \\
(\%)\end{array}$ & $\begin{array}{c}\text { HA } \\
(\%)\end{array}$ & $\begin{array}{l}\text { FA } \\
(\%)\end{array}$ & $\begin{array}{c}\text { HA/FA } \\
\text { ratio }\end{array}$ & $\mathbf{Q}_{4 / 6}$ & DH & pH (KCl) \\
\hline \multirow{3}{*}{$\begin{array}{c}\text { Beech } \\
1\end{array}$} & $\mathbf{F}+\mathbf{H}$ & 15.20 & 26.20 & 2.97 & 1.36 & 1.61 & 0.85 & 5.09 & 19.53 & 5.43 \\
\hline & $\mathbf{A h}$ & 5.30 & 9.14 & 1.68 & 0.65 & 1.04 & 0.62 & 4.85 & 31.75 & 4.93 \\
\hline & Bmtl & 0.10 & 0.17 & 0.63 & 0.16 & 0.47 & 0.34 & 4.16 & - & 3.49 \\
\hline \multirow{3}{*}{$\begin{array}{c}\text { Beech } \\
2\end{array}$} & $\mathbf{F}+\mathbf{H}$ & 16.00 & 27.58 & 2.97 & 1.39 & 1.58 & 0.88 & 4.06 & 18.55 & 5.34 \\
\hline & $\mathbf{A h}$ & 5.30 & 9.14 & 2.37 & 1.04 & 1.34 & 0.78 & 5.28 & 44.77 & 4.84 \\
\hline & Bmtl & 0.20 & 0.34 & 0.41 & 0.16 & 0.25 & 0.66 & 4.43 & - & 3.64 \\
\hline
\end{tabular}

Note: HS - humic substances; HA - humic acids; FA - fulvic acids; Q $_{46}$ - colour quotient; $\mathrm{DH}$ - degree of humification

In soil horizon Ah (Tab. 4) of the beech stand variants the humus content is high (>9\%). The same applies to the sum of HL $(>1.68 \%)$. The quality of humus is however low. For the fractional composition, fulvic acids (FA) are predominant of humic acids (HA). The HA to FA ratio is less than 1 . The values of colour index $\mathrm{Q}_{4 / 6}$ were determined to range from 4.8 to 5.3 , indicating acidic fulvate type of humus. The degree of humification is high (>30\%). The rate of absorbance in the UV-VIS spectral region is higher than for Bmt horizon, but lower than in the layer of $\mathrm{F}+\mathrm{H}$ humus.

For Bmt soil horizon the humus content is very low $(<0.5 \%)$. The same applies to the sum of HL $(<1.0 \%)$. Humus quality is very low. In the fractional composition fulvic acids (FA) strikingly prevail over humic acids (HA). The HA to FA is less than 0.7 (0.5 for Beech 1 variant). The values of colour index $\mathrm{Q}_{4 / 6}$ were determined to exceed 4 , indicating acidic fulvate type of humus. The degree of humification could not be determined due to the very low organic carbon content. The rate of absorbance in the UV-VIS spectral region is very low. The results obtained from the fractionation of humic substances showed no significant differences between the thinning variants at those sites - currently, thinning do not have a significant impact on these parameters.

\section{Multivariate statistical analysis}

Only the first two axes shown in the graph of component weight PC1 and PC2 (Fig. 3); they together deplete around $93 \%$ of the variability. Axis PCl clearly outlines the fractionation of humic substances (HL, HA, FA; to some extent, $\mathrm{C}_{\text {org }}$ and the HA to FA as well); the substances are then running straight along the axis and are correlated to it, via 0.9 (HL, HA, FA) and, to some extent, even with both $\mathrm{C}_{\text {org }}(0.6-0.7)$ and the HA to FA ratio (0.6-0.8). Soil horizons are split along PCl as well; most of $\mathrm{C}_{\text {org }}$ and the humic substances exist in the $\mathrm{F}+\mathrm{H}$ and $\mathrm{Ah}$ layers of beech stands in comparison with those of spruce. In spruce stands, the contents are also much more balanced between the horizons; in beech stands, they differ to a greater extent.

The PC2 axis lacks considerable correlation; rather, directions are characterised, depending on e.g. $Q_{4 / 6}$ (conversion of humic substances is better under the beech stands), $\mathrm{pH}$ (higher in all layers and horizons under the beech stands compared to stands of spruce), and C/N to DH 


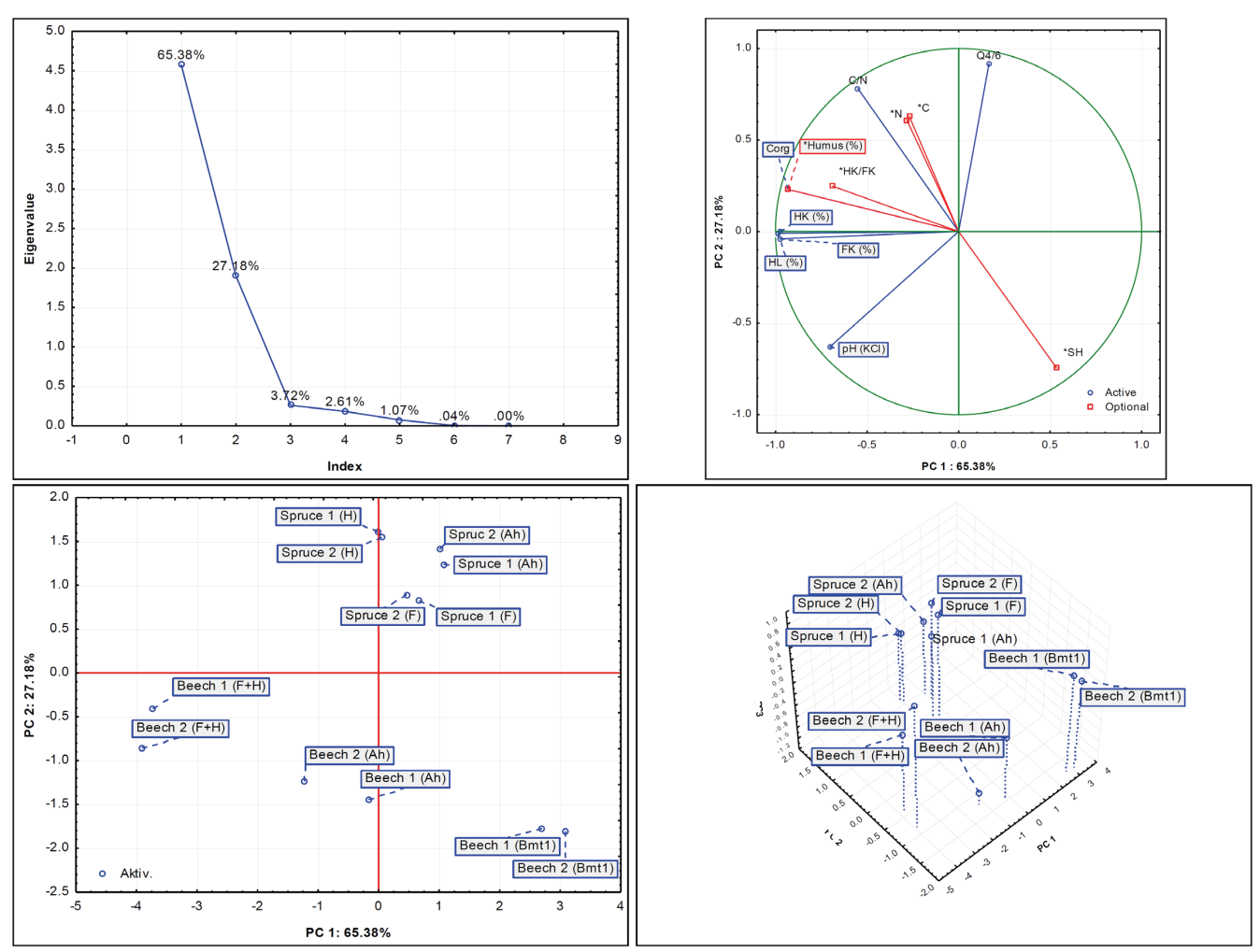

Fig. 3. Multivariate statistical PCA analysis in the layers of forest floor and soil horizons - spruce and beech stand variants.

ratio (conversion of humic substances is better under the beech stands). $\mathrm{Q}_{4 / 6}$ and $\mathrm{pH}$ are strongly negatively correlated (0.7); the same applies to the $\mathrm{C} / \mathrm{N}$ to $\mathrm{DH}$ ratio (0.6).

PCA analysis (the PCl and PC2 axes) significantly characterised two categories: tree species composition (spruce and beech stands), and the influence of the habitat (acid and nutrient sites). It also confirmed that a thinning has not a statistically significant effect on humus conditions in young stands of spruce and beech at various types of habitats.

\section{Discussion}

The stock of forest floor found in the Spruce 2 stand was found to be larger than for Spruce 1; the difference was 4.7 t.ha $^{-1}$ ). Klimo, Maršálek (1992) detected a total stock of the surface humus layer being 50 t.ha ${ }^{-1}$ in 1977 before the previous mature stand was harvested; after the logging operation, when a new stand (i.e. the existing one) was set up in 1978, there was an increase to 72 t.ha' ${ }^{-1}$ as a result of the used method (wholetree logging). After 14 years, in 1991, the forest floor stock was 63 t.ha' ${ }^{-1}$ throughout the research area (Klimo, Maršálek 1992). In comparison with previous studies, there is a clear decrease in the stock of the humus material, mainly in layer $\mathrm{H}$ (from about 40 to 23 t.ha $^{-1}$ ). Conversely, the F layer stock arouse from 10 to 21 t.ha ${ }^{-1}$. The stock in beech stands was set at 17.1 to 20.5 t.ha1. Menšík et al. (2009b) report the stock of the surface humus layer amounting to 79.4 t.ha $^{-1}$ for spruce stands aged 60 years approximately and found at $3 \mathrm{~K}$ sites with acidic cambisol and moder humus form; at 4H sites of good carrying capacity the level was 53.6 t.ha-1 in spruce stands, 29.5 t.ha ${ }^{-1}$ in spruce-beech stands and 25.0 t.ha $^{-1}$ in Douglas fir stands. Furthermore, Pernar et al. (2008) reports the level of stock in the surface humus layer to be $49.5 \mathrm{t}^{-h a^{-1}}$ in mixed selection woods of fir, beech and spruce found on dystric cambisol with the moder form of surface humus in Gorski Kotar (Croatia).

Based on the carbon content and the stock (forest floor and soil), carbon stock was estimated in the forest floor and in a soil layer to a depth of $50 \mathrm{~cm}$; it ranged from 89 to 99 t.ha $^{-1}$ in spruce stands (about 22 to 27 t.ha-1 in the forest floor and 68 to 72 t.hat $^{-1}$ in the soil). In beech stands, the stock was set at $82 \mathrm{t}^{-\mathrm{Ha}^{-1}}$ (about 5 t.ha ${ }^{-1}$ in the forest floor and 77 t.ha $^{-1}$ in the soil). 
Similar results were reported by Reichle (1981) in 1980 as part of the Solling project, giving the stock of carbon for a spruce stand aged 87 years to be 24.5 t.ha $^{-1}$ in the forest floor and 95 t.ha $^{-1}$ in the soil. Menšík et al. (2009b) report the stock of carbon in the surface humus layer amounting to $34.0 \mathrm{t}^{-h^{-1}}$ for spruce stands found at $3 \mathrm{~K}$ sites with oligotrophic cambisol and moder humus form; at 4H rich sites with mesotrophic cambisol the level was 22.0 t.ha $^{-1}$ in spruce stands, 8.5 t.ha $^{-1}$ in mixed stands. Vesterdal et al. (1995) reported the forest floor stock of carbon in spruce stands aged 47-51 years with differing thinning (N.ha-1 1646-2000, similar to Spruce 1, 2) in Denmark to range from 15 to $17 \mathrm{t}$.ha-1. Results for nitrogen stock in spruce and beech stands are similar to those reported by Menšík et al. (2009a, b) for spruce, beech, mixed and Douglas fir stands under similar natural settings.

The quality of humus fractions, i.e. humic and fulvic acids, are an important soil characteristics (Brady, Weil 2008). Often, the quality is assessed by the humic acid to fulvic acid ratio (HA to FA) (Aranda, Oyonarte 2006; Dai et al. 2006). With increasing levels of humic acids the quality of humus becomes improved. For humus of top quality the HA to FA ratio should be greater than 1.5 to 1 (Pospíšilová, Tesařová 2009). A lower HA to FA rate (less than 1.0) is found in the layer $\mathrm{H}$ and horizon Ah of both beech and spruce stands. A term "degree of humification" was introduced to provide a more detailed characterisation of transformation of humic substances in the soil (Sotáková 1982; Zanelli et al. 2006). The transformation of humic substances (DH I) is more complete in $\mathrm{H}$ layer under the spruce stands compared with beech stands. Within the Ah horizon, the situation is reversed, the transformation of humic substances being more complete under the beech stands. Colour quotient $\left(Q_{4 / 6}\right)$ is used for the characterisation of humic substances when evaluating the optical properties of humus. The lower the colour quotient value, the more the leached organic compounds polymerise and the better is the quality they reach in terms of stability of the soil (Pospíšilová, Tesařová 2009). The UV/VIS spectra of humic acids are closely related to the $\mathrm{Q}_{4 / 6}$ ratio. The UV/VIS spectra in the forest floor (horizon $\mathrm{H}$ ) showed that the absorbance in spruce stands is the same but the curve is steeper. In contrast, absorbance is lesser and less steep for beech stands. More distinct (lesser) absorbance is found in the Ah horizon under the beech stands compared with stands of spruce. This is confirmed by the $\mathrm{HA}_{4 / 6}$ ratio.

\section{Conclusion}

The study evaluated the effect of the type of thinning (above thinning vs. below thinning) on the humus conditions (i.e. forest floor stock, the content and stock of carbon and nitrogen, $\mathrm{C} / \mathrm{N}$ ratio, and the proportion of carbon in humic substances) in spruce stands found on acid granodiorite (acid site) in forest vegetation zone 4 to 5 (Field research station Rájec-Němčice) and in beech stands found on a solidified limestone sediment (nutrient rich site) in FVZ 3 to 4 (TFE Krrtiny); the sites indicated above are part of the Drahanská vrchovina Upland. Thinning was conducted in spruce stand in 2005, 2010; in beech stand in 2011.

The obtained results permit drawing the following conclusions:

- The stock of forest floor was set at 17 to $18 \mathrm{t}^{-h^{-1}}$ under the stands of beech (Beech 1,2) and 51 to $54 \mathrm{t}^{-h a^{-1}}$ in the stands of spruce (Spruce 1, 2); thinning currently do not have a significant impact on the stock of humus, while the effect of habitat (or tree species, where appropriate) is significant.

- The stock of carbon/nitrogen in the forest floor was set at 20 to 21 (0.7) tha ${ }^{-1}$ in spruce stands (Spruce 1, 2); for beech stands (Beech 1,2 ) it was calculated to amount to 4-5 (0.1 to 0.2) t.ha ${ }^{-1}$. The stock of carbon/nitrogen in the soil (to a depth of $50 \mathrm{~cm}$ ) ranges from 66 to 77 ( 3 to 7 ) t.ha ${ }^{-1}$; thinnig felling currently have no significant effect.

- $\mathrm{C} / \mathrm{N}$ ratio in the individual layers of forest floor and soil horizons within the stands (both spruce /Spruce 1, 2/ and beech /Beech 1,2/) is similar at each of the sites, i.e. do not significantly differ (no statistically significant differences recorded); thinning have currently no significant effects.

- Fulvic acids are prevalent in the stands of both spruce (Spruce 1,2) and beech (Beech 1,2 ) in the layer $F$ and $H$ as well as horizon Ah - a lower HA to FA ratio (less than 1.0); the transformation of humic substances (DH I) is more complete in layer $\mathrm{H}$ under the spruce stands (Spruce 1, 2) compared with stands of beech (Beech 1, 2). In the Ah horizon, the situation is reversed with the transformation of humic substances being better under the beech stands; the $\mathrm{Q}_{4 / 6}$ ratio in the forest floor layers $\mathrm{H}(\mathrm{F}+\mathrm{H})$ and $\mathrm{Ah}$ horizon was higher under the spruce stands (Spruce 1, 2) compared with stands of beech (Beech 1, 2); UV/ VIS spectra in the forest floor, horizon $\mathrm{H}$, showed that the absorbance in spruce stands 
(Spruce 1,2) is the same, the curve is however steeper. In contrast, absorbance in beech stands (Beech 1,2) is lesser and less steep. More distinct (lesser) absorbance is found in the Ah horizon under the beech stands compared with stands of spruce. This is confirmed by the $\mathrm{HA} \mathrm{Q}_{4 / 6}$ ratio - these characteristics are unaffected by thinning; they however are influenced by type of habitat (acid site, nutrient rich site), species structure (Spruce, Beech), climatic conditions, etc.;

- PCA analysis confirmed that thinning has no statistically significant effect on humus conditions in young spruce and beech stands at sites of different types.

\section{Acknowledgement}

The study was developed under the financial support of the research project entitled IGA LDF 33/2014 "The effect of the strong increment thinning - synthesis of the ecological-production study", and the research project of Ministry of Education of the CR, project COST LDI4018 "Sustainable management of mixed forests in highland areas".

\section{References}

Aranda, V., Oyonarte, C. 2006: Characteristics of organic matter in soil surface horizon derived from calcareous and metamorphic rocks and different vegetation types from the Mediterranean high mountains in SE Spain. European Journal of Soil Biology, 42: 247-258.

Binkley, D., Giardina, C. 1998: Why do tree species affect soil? The Warp and Woof of treesoil interactions. Biogeochemistry, 42: 89-106.

BRAdy, N.C., WeIL, R.R. 2008: The nature and properties of soil. 14 $4^{\text {th }}$ edition. Pearson Prentice Hall, Upper Saddle River, New Jersey, Columbus, Ohio. 975.

DaI, J., RAN, W., XING, B., Gu, M., WANG, L. 2006: Characterization of fulvic acid fractions obtained by sequential extractions with $\mathrm{pH}$ buffers, water and ethanol from paddy soils. Geoderma, 135: 284-295.

JandÁk, J., Pokorný, E., Hybler, V., PospíšIllová, L. 2003: Soil science learning book. Mendel University in Brno, 92. (in Czech)

KLIMO, E, MARŠÁLEK, J. 1992: Manmade Spruce Ecosystem (Structure, Functions, Production, Processes). Report from Project Rájec, Institute of Forest Ecology, Agriculture University Brno, 177.

Kononova, M.M. 1963: Organičeskoe veščestvo počvy. I.A.N. SSSR: Moskva. 311 pp.
Meloun, M., MiцitкÝ, J. 2012: The interactive statistical analysis. 4. Edition, Karolinum Praha, 955. (in Czech)

Meloun, M., MiцitKÝ J. 2011: Statistical Data Analysis, A Practical Guide with 1250 Exercises and Answer key on $C D$, Woodhead Publishing India, 1600.

MENŠí, L. 2010: Fractionation of humus substances of forest soils. Dissertation thesis, Mendel University in Brno, 210.

Menší, L., Fabiánek, T., Tesař, V., Kulhavý, J. 2009a: Humus conditions and stand characteristics of artificially established young stands in the process of the transformation of spruce monocultures. Journal of Forest Science, 55 (5): 215-223.

Menšík, L., Kulhavצ́, J., Kantor, P., Remeš, M. 2009b: Humus conditions of stands with the different proportion of Douglas fir in training forest district Hůrky and the Krrtiny Forest Training Enterprise. Journal of Forest Science, 55 (8): 345-356.

Menšík, L., Kulhavצ́, J., MareČek, J. 2012: Accessory equipment for sampling of forest floor in the forest ecosystems. Functional sample. Mendel University in Brno.

NĚMečeK, J., MackỦ, J., Vokoun, J., VaVŘ́č́eK, D., NovÁK, P. 2011: The taxonomic soil classification system in the Czech Republic, 2. Edition. Czech University of Life Sciences in Prague, 94. (in Czech)

Nilsen, P., Strand, L.T. 2008: Thinning intensity effects on carbon and nitrogen stores and fluxes in a Norway spruce (Picea abies (L.) Karst.) stand after 33 years. Forest Ecology and Management, 256 (3): 201-208.

NovÁK, J., SLODIČÁK, M. 2004: Structure and accumulation of litterfall under Norway spruce stands in connection with thinnings. Journal of Forest Science, 50 (3): 101-108.

NovaK, J., SLODICAK, M., DuseK, D. 2011: Thinning effects on forest productivity and site characteristics in stands of Pinus sylvestris in the Czech Republic. Forest Systems, 20 (3): 464-474.

OrLov D.S. 1985: Chimija počv (Soil Chemistry). Moskva: Izd. MGU, 376.

Pernar, N., Matić, S., Bakšić, D., Klimo, E. 2008: The accumulation and properties of surface humus layer in mixed selection forests of fir on different substrates. Ekologia Bratislava, 27 (1): 41-53.

Pivec J. 1992: Air Temperature and Deficit of Precipitation. In: Klimo E, Maršálek J. (Ed.) Manmade Spruce Ecosystem (Structure, Functions, Production, Processes). Report from Project Rájec, Institute of Forest Ecology, Agriculture University Brno, 9-10. 
PodlešÁkovÁ, E., NĚMeČEK, J., SiRovÝ, V., LhotskÝ, J., Macurová, H., Ivánek, O., Bumerl, M., Hudcová, O., Voplakal, K., Hálová, G., Blahovec, F. 1992: Analyses of soil, water and plants. VÚMOP, Praha, 259. (in Czech)

PodrÁZsKÝ, V., NovÁK, J., Moser, W.K. 2005: Effect of thinning on amount and character of the surface humus in mountain spruce stand. Zpráoy Lesnického Výzkumu, 50 (4): 225-228. (in Czech)

PospíšilLovÁ, L., TesaŘovÁ, M. 2009: Organic carbon in arable soils. Folia Universitatis Agriculturae et Silviculturae Mendelianae Brunensis, Edition of original papers and monographs. II (1): 1-41. (in Czech)

REICHLE, D.E. 1981: Dynamic properties of forest ecosystems. Cambridge University Press, 683.

ŠÁLY, R. 1978: The soil - the basis of forestry production, Bratislava, Príroda, 235. (in Slovak)

ŠARMAN, J. 1979: The influence of thinning on the state of the forest floor in fir stands. Lesnictví, 25 (7): 595-604. (in Czech)

ŠARMAN, J. 1982: Influence of thinning on the forest floor in the spruce stand. Lesnictví, 28 (1): 31-42. (in Czech)

SotÁкоvÁ, S. 1982: Organic matter and soil fertility. Príroda Bratislava. 234. (in Slovak)

StATSOFT ČR s.r.o. 2014: STATISTICA.Cz, verze 12.0. www.statsoft.cz.

Stevenson, F.J. 1994: Humus Chemistry, Genesis, Composition, Reactions. John Wiley \& Sons, Inc., New York, 496.

TruHLÁR̆, J. 1996: Silviculture of Forests in the Biological concept. Brno, MZLU, ŠLP: 117. (in Czech)

Vesterdal, L., Dalsgaard, M., Felby, C., RaulunDRASMUSSEN, K., JORGENSEN, B.B. 1995: Effects of thinning and soil properties on accumulation of carbon, nitrogen and phosphorus in the forest floor of Norway spruce stands. Forest Ecology and Management, 77: 1-10.

Zanelli, R., Egli, M., Mirabella, A., Giaccai, D., FITZE, P. 2006: Influence of laurophyllous species, Castanea sativa and Quercetum-Betuletum vegetation on organic matter in soils in southern Switzerland and northern Italy. Geoderma, 136: 723-737.

Zbíral, J., Honsa, I., Malý, S. 1997: Soil Analysis. III. Unified Working Procedures. Brno, ÚKZÚZ, 150. (in Czech) 